
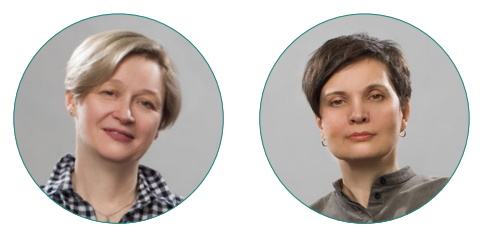

Ж. В. Чернова, Л. Л. Шпаковская

\title{
ПРЕПОДАВАТЕЛЬСКИЙ ТРУД В УСЛОВИЯХ ПАНДЕМИИ: АКАДЕМИЧЕСКИЙ НЕОЛИБЕРАЛИЗМ И ЭМОЦИОНАЛИЗАЦИЯ
}

\section{Правильная ссылка на статью:}

Чернова Ж.В., Шпаковская Л. Л. Преподавательский труд в условиях пандемии: академический неолиберализм и эмоционализация // Мониторинг общественного мнения: экономические и социальные перемены. 2021. № 3. С. 155-178. https://doi.org/10.14515/ monitoring.2021.3.1924.

\section{For citation:}

Chernova Z. V., Shpakovskaya L. L. (2021) Teaching During a Pandemic: Academic Neoliberalism and Emotionalization. Monitoring of Public Opinion: Economic and Social Changes. No. 3. P. 155-178. https://doi.org/10.14515/monitoring.2021.3.1924. (In Russ.) 
ПРЕПОДАВАТЕЛЬСКИЙ ТРУД В УСЛОВИЯХ ПАНДЕМИИ: АКАДЕМИЧЕСКИЙ НЕОЛИБЕРАЛИЗМ И ЭМОЦИОНАЛИЗАЦИЯ

ЧЕРНОВА Жанна Владимировна доктор социологических наук, ведущий научный сотрудник, Социологический институт РАН - филиал Федерального научно-исследовательского социологического центра Российской академии наук, Санкт-Петербург, Россия; доцент факультета свободных искусств и наук, Санкт-Петербургский государственный университет, Санкт-Петербург, Россия

E-MAIL: chernova30@mail.ru

https://orcid.org/0000-0003-3416-5287

ШПАКОВСКАЯ Лариса Леонидовна кандидат социологических наук, старший научный сотрудник, Социологический институт РАН - филиал Федерального научно-исследовательского социологического центра Российской академии наук, Санкт-Петербург, Россия E-MAIL: slarisalarisa@gmail.com https://orcid.org/0000-0002-4206-4702

Аннотация. В статье изучается изменение содержания труда преподавателей, практик преподавания и моделей взаимодействия в виртуальном учебном классе, трудозатрат на выполнение профессиональных обязанностей и их типов. Рассматривается переопределение баланса труда и отдыха во время вынужденного перехода на дистанционную форму обучение в период пандемии COVID-19. Мы изучаем, как преподаватели видят свою работу, как структурируют рабочее время и время отдыха, а также какие стратегии адаптации к новым условиям труда и жизни они вырабатывают.
TEACHING DURING A PANDEMIC: ACADEMIC NEOLIBERALISM AND EMOTIONALIZATION

Zhanna V. CHERNOVA ${ }^{1,2}-$ Dr. Sci. habil. (Soc.), Leading Researcher; Associate Professor of the Faculty of Liberal Arts and Sciences

E-MAIL: chernova30@mail.ru

https://orcid.org/0000-0003-3416-5287

Larisa L. SHPAKOVSKAYA ${ }^{1}$ - Cand. Sci. (Soc.), Senior Researcher E-MAIL: slarisalarisa@gmail.com https://orcid.org/0000-0002-4206-4702

\footnotetext{
${ }^{1}$ Sociological Institute of the RAS - a Branch of the Federal State Budgetary Institution of Science of the Federal Research Sociological Center of the Russian Academy of Sciences, Saint Petersburg, Russia

2 Saint Petersburg State University, Saint Petersburg, Russia
}

Abstract. The article examines the change in the content of teachers' work, teaching practices and models of interaction in a virtual classroom, as well as labor costs for performing professional duties and their types. The authors consider redefining the balance of work and leisure during the forced transition to distance learning during the COVID-19 pandemic focusing on how teachers see their work, how they structure their working and leisure time, and what strategies they develop for adapting to new working and living conditions. 
Вынужденный переход на онлайнформат обучения потребовал от университетских преподавателей оперативно перестроить практики работы, переопределить место и содержание труда в контексте изменений границ между публичной и приватной сферами, вписать свои профессиональные обязанности в новый формат повседневной жизни в режиме самоизоляции. В статье применяются основные положения социологии повседневности (И. Гофман), с фокусом на микроуровне анализа повседневных коммуникаций; и социологии эмоций (А. Хокшилд). Эмпирическими материалами исследования выступили полуструктурированные интервью с преподавателями российских университетов ( $\mathrm{N}=28)$. Анализ этих данных позволил сформулировать ряд выводов и дал возможность понять, какие стратегии онлайн-обучения студентов и модели взаимодействия в виртуальном учебном классе выработали преподаватели, адаптируясь к вынужденному переходу на дистанционный формат работы, как изменение места и содержания труда преподавателей определило пересмотр политик контроля своего времени и трудозатрат, в том числе возрастание нагрузки по выполнению эмоциональной работы в ситуации уплотнения и гетеротопичности пространства. В целом вынужденный массовый переход преподавателей на дистанционную форму работы актуализировал проблематику содержания труда преподавателя, его подотчетности административным структурам и формальным правилам регламентации, а также обострил социальные неравенства в контексте неолиберальной академии.
The forced transition to an online learning format demanded that university teachers quickly restructure their work practices, redefine the place and content of work in the context of changing boundaries between the public and private spheres, and fit their professional duties into a new regime of daily life in self-isolation. The article applies the main provisions of the sociology of everyday life (Erving Goffman), with a focus on the micro-level of the analysis of everyday communications, and the sociology of emotions (Arlie Russell Hochschild). The empirical base of the study consists of 28 semi-structured interviews with professors from Russian universities. The analysis of these data made it possible to formulate a number of conclusions and to understand what strategies for online teaching and interaction in a virtual classroom the teachers developed while adapting to the forced transition to a distance format. It also reveals how the change in the place and content of teachers' work determined the revision of the policies for controlling their time and labor costs, including an increase in the amount of emotional work in a situation of compaction and heterotopicity of space. In general, the forced massive transition of teachers to the remote work has actualized the problems related to the content of their work and their accountability to administrative structures and formal rules of regulation, and exacerbated social inequalities in the context of the neoliberal academy. 
Ключевые слова: академическая профессия, университет, пандемия, баланс труда и жизни, социальные неравенства, эмоциональная работа

Благодарность. Статья подготовлена в рамках НИР "Развитие образовательной модели свободных искусств и наук (Liberal Arts) в условиях цифровизации" (РАНХиГС, 2020 г., ID проекта в системе Pure СПбГУ 53583510).
Keywords: academic career, university, pandemic, social inequalities, emotional work

Acknowledgments. The article was prepared within the research project "Development of the educational model of liberal arts and sciences (Liberal Arts) in the context of digitalization" (RANEPA, 2020, project ID in the Pure system of St. Petersburg State University 53583510).

Эпидемия коронавируса и введение ограничительных мер создали уникальную ситуацию переформатирования работы многих социальных институтов, "Глобальной поломки" устоявшихся структур повседневности. Институционально санкционированные изменения повседневных образовательных практик и кодифицированных правил работы профессорско-преподавательского состава существенно изменили порядок деятельности высших учебных заведений в период введения режима вынужденной самоизоляции. 16 марта 2020 г. Министерство науки и высшего образования РФ рекомендовало вузам полностью перейти на дистанционную форму обучения ${ }^{1}$, в связи с чем они были вынуждены кардинально перестроить работу, в массовом порядке внедряя новые технологические и организационные решения. Эти изменения коренным образом трансформировали не столько содержание учебного процесса, сколько способы выполнения преподавательского труда.

Цифровые технологии в ведущих российских университетах активно использовались в учебном процессе еще до введения режима самоизоляции, однако большинство преподавателей рассматривали онлайн-компонент образовательного процесса как факультативное дополнение к основной деятельности в аудитории [Абрамов и др., 2020]. С началом “дистанционного форс-мажора" учебные IT-технологии переместились в центр преподавательской деятельности, став главным средством коммуникации со студентами и другим персоналом и таким образом существенно реструктурировав учебный процесс. Массовый переход на онлайн-обучение потребовал от университетских преподавателей не только быстро перестроить профессиональные практики, но и переопределить место и содержание своего труда в контексте изменений границ между публичной и приватной сферами, а также вписать свои профессиональные обязанности в новый формат повседневной жизни в режиме самоизоляции.

В данной статье нас интересует, как в связи с вынужденным массовым переходом на дистанционный формат обучения изменились содержание труда пре-

\footnotetext{
1 Агранович М. Минобрнауки рекомендовало вузам организовать дистанционное обучение // Российская газета. 2020. 15 марта. URL: https://rg.ru/2020/03/15/minobrnauki-rekomendovalo-vuzam-organizovat-distancionnoeobuchenie.html (дата обращения: 23.06.2021).
} 
подавателей, практики преподавания и модели взаимодействия в виртуальном учебном классе, трудозатраты преподавателей, а также место эмоционального труда в учебном процессе в новых условиях.

\section{Академический капитализм и эмоционализация труда преподавателей}

Общим контекстом, в котором реализовывался массовый переход на онлайнобучение, выступает специфика организации работы высшей школы и содержания академической профессии в целом. Исследователи отмечают, что общемировым трендом изменений является использование неолиберальных принципов в организацию работы университетов [Giroux, 2002; Schwartz, 2014; Darde, 2012]. Под либерализацией вузов понимается внедрение рыночных механизмов в управление образовательной деятельности [Шпаковская, 2007: 56]. В неолиберальной трактовке университеты начинают определяться не как учреждения, деятельность которых связана с производством образования и знания как общего блага, а как коммерческие предприятия, ориентированные на получение прибыли и повышение эффективности своей работы. Эти изменения также часто определяют в терминах "менеджериальной революции" [Абрамов, 2007], подразумевая процесс перехода власти внутри вузов от академиков к администраторам и управленцам [Дим, 2004]. Кроме того, неолиберальные принципы предполагают позиционирование процесса образования как предоставления образовательных услуг, а студентов и их родителей - как клиентов и потребителей, которые выбирают и приобретают образовательные сервисы. Как коммерческие предприятия, ожидающие производительности от своих сотрудников, вузы также вводят различные механизмы оценки эффективности работы преподавателей, например эффективные контракты. В результате труд преподавателей становится все более подотчетным внешнему контролю и квантификации его результатов в виде набора фиксированных показателей, таких как количество публикаций, индекс цитирования, объем привлекаемых за счет грантовой деятельности средств, число бакалаврских, магистерских, кандидатских и докторских диссертаций, защищенных под руководством конкретного преподавателя [Allen, 2017; Schwartz, 2014].

Студенты также становятся внешним агентом контроля работы преподавателей, поскольку участвуют в процессе оценивания труда профессорскопреподавательского состава, выставляя баллы по формальным разработанным администрацией шкалам. Преподаватели все чаще переводятся на краткосрочные трудовые контракты, что позволяет администрации осуществлять гибкую кадровую политику и дает ей дополнительные рычаги контроля за их деятельностью. Оплата труда, продвижение по карьерной лестнице, заключение и продление контрактов преподавателей напрямую увязываются с показателями результативности их труда (оценка публикационной и грантовой активности, рейтинг преподавателя на основе студенческих оценок). Глобальные процессы неолиберализации академии способствуют потере автономии преподавательской профессии, сокращению академической власти преподавателей, а также создают дополнительную нагрузку и увеличивают стресс у профессорско-преподавательского состава [Абрамов, Груздев, Терентьев, 2019; Абрамов, 2016; Прудников, 2016]. Таким образом, квантификация результатов преподавательского труда делает его более подот- 
четным внешнему, часто разноплановому контролю со стороны нескольких агентов: администрации университета, студентам, профессиональному сообществу. При этом объем привлекаемых средств (за счет количества студентов, грантовой деятельности или других видов работы) фактически становится главным критерием оценки результативности деятельности университетов и их сотрудников. Преподаватели, адаптируясь к «академическому капитализму» [Slaughter, Rhoades, 2004], вынуждены переопределять содержание своей деятельности, оптимизировать усилия для сохранения позиции в системе университетской иерархии путем перераспределения усилий на выполнение различных видов академического труда [Schwartz, 2014].

Пандемия, изменив условия труда и актуализировав новые технологические возможности, произвела новые риски и вызовы академической профессии в условиях устойчивых тенденций, характерных для неолиберальной академии в целом [King, Hurst, Lewis, 2020]. Вынужденный массовый переход на онлайнформат обучения в середине академического 2019/2020 года заставил многих преподавателей не только адаптировать разработанный под формат офлайнпреподавания дизайн курса, пересмотреть выработанные ранее методики преподавания, но и искать новые формы организации взаимодействия со студентами в виртуальном классе, а также переопределить содержание своего труда и границ между работой и личной жизнью.

\section{Концепция эмоционального труда как теоретическая рамка исследования академии}

Концепция эмоционального труда как отдельного измерения труда была введена Арли Хокшилд для того, чтобы подчеркнуть роль эмоций в производстве экономической стоимости. От современного работника требуются особые навыки по управлению эмоциями и чувствами в зависимости от контекста ситуации взаимодействия. При этом индивид может играть роль "режиссера" социального взаимодействия, который сам продумывает сценографию, подбирает соответствующий реквизит, мимику и жесты. Однако, по мнению Хокшилд, институты также имеют большое значение в регулировании эмоционального труда индивидов. Они экспроприируют у них отдельные элементы актерской игры и замещают их институциональными механизмами, регулирующими и поддерживающими правила исполнения той или иной роли. Институты обустраивают свои авансцены, берут на себя режиссерские функции, задают правила взаимодействия между акторами, таким образом управляя тем, что чувствуют индивиды [Хокшилд, 2019: 173-188]. При этом подходе эмоциональный труд становится частью профессиональных компетенций и навыков работников практически во всех сферах занятости. Он регламентируется институциональными правилами эмоциональной экспрессии, предоставляемым институтами реквизитом и их способами организации пространства как сцен социального взаимодействия. Хокшилд показала ключевую роль эмоционального труда в сервисных профессиях, где он оказывается важной частью работы, оставаясь при этом незамечаемым и неоплачиваемым со стороны работодателя, что приводит к эксплуатации и высоким человеческим издержкам (эмоциональное выгорание, амбивалентность, цинизм исполнителей) работников [Хокшилд, 2019]. 
Исследования преподавательского труда как части академической работы показывают смычку академического неолиберализма и эмоционального капитализма [IIlouz, 2007] в связи с тем, что неолиберальный университет становится все больше зависим от рынка и ресурсов, приносимых студентами. Университеты переопределяют студентов как своих клиентов, рассматривая образование в качестве услуги, предоставляемой на образовательном рынке. Таким образом преподавательский труд реинтерпретируется как сервисная функция, ориентированная на удовлетворение широкого спектра запросов студентов: от когнитивных и образовательных до физического и эмоционального благополучия [Lawless, 2018; Gretzky, Lerner, 2021]. Вследствие этого эмоциональный труд, как и в любой сервисной профессии, становится важным компонентом преподавательской работы в современных университетах.

Эмоциональный труд преподавателя включает выражение симпатии и эмпатии, поддержание внимания, демонстрацию поддерживающего и вовлеченного стиля коммуникации, создание в аудитории комфортной эмоциональной атмосферы [Lawless, 2018; Magoqwana, Maqabuka, Tshoaedi, 2019]. Преподаватели также должны выполнять эмоциональную работу, справляясь с постоянным стрессом, порождаемым подотчетностью и необходимостью демонстрации собственной эффективности, возникающих в условиях неолиберальной академии. Они также должны контролировать свои эмоции в учебной аудитории, избегать любых проявлений (микро)агрессии, выражать поддержку и понимание в отношении студентов то есть демонстрировать позитивный эмоциональный дисплей. Работа по осуществлению заботы предполагает создание эмоционально комфортных условий как для студентов, так и для коллег, может быть связанной с выражением эмпатии, неформальной помощи и поддержки в решении самых разных вопросов, не связанных напрямую с образовательным процессом. Таким образом, преподавательский труд, как любая сервисная работа, имеет гендерное измерение. Он нередко ассоциируется с "естественными" качествами женственности, попадая в один ряд с другими профессиями "розовых воротничков" [Larson, 2008]. Неолиберализация университетов приводит к изменению паттернов гендерного и статусного неравенства, связанного с выполнением эмоционального труда и труда по осуществлению заботы [Winslow, Davis, 2016; Перес, 2019].

\section{Методы и эмпирическая база исследования}

Для изучения изменений в содержании преподавательского труда в период пандемии были проведены полуструктурированные интервью с преподавателями и представителями администраций вузов (март - июль 2020 г.) четырех университетов (как региональных, так и столичных), $N=28$. Критерии отбора университетов были следующие:

- высокая степень либерализации образования, под которой мы понимали наличие большой доли студентов, обучающихся на платной основе;

- внедрение принципа выборности курсов и индивидуальных образовательных маршрутов;

- наличие процедур рейтингования как студентов, так и преподавателей в качестве обязательного элемента управления образовательным процессом. 
Интервью проводились онлайн из-за введенного режима самоизоляции в доверительной обстановке, а также в соответствии с этическими нормами социологического исследования ${ }^{2}$.

Гайд интервью помимо биографического блока включал вопросы о преподавательской, административной и научной работе информанта, а также о коммуникациях со студентами до и во время перехода на онлайн-обучение. Нас интересовали такие аспекты образовательных практик информантов, как формат проведения лекционных и семинарских занятий, формы домашних заданий и отчетности по читаемым курсам, тип и средства поддерживаемой коммуникации со студентами в аудитории и за ее пределами, институционализированные и неформальные практики взаимодействия студентов и преподавателей, а также опыт использования онлайн-технологий и образовательных платформ в учебном процессе, оценка перспектив развития онлайн-формата образования в целом. Кроме этого, мы спрашивали, каким образом переход на онлайн-формат преподавания повлиял на баланс работы и семьи, как изменился график занятости информантов.

Транскрипты всего массива данных интервью кодировались при помощи программы ATLAS.ti с использованием метода тематического анализа [Flick, 2006: 307-312]. Единицей анализа выступал тематический нарратив, посвященный отдельным аспектам учебного процесса и взаимодействия со студентами. На основе кодирования были выделены тематические категории, используемые информантами для описания и интерпретации своего повседневного опыта перехода на онлайн-преподавание: “организация учебного процесса до начала карантина", "организация лекций, семинарских занятий, объема и формата домашних заданий до начала карантина", "восприятие труда преподавателя до начала карантина", "восприятие процесса перехода на онлайн-обучение", "эмоции в процессе перехода на онлайн-обучение", "проблемы в организации работы и повседневности во время карантина", "использование технических средств во время карантина для осуществления образовательного процесса", "практики управления временем и организации пространства в период карантина". Аналитическая интерпретация значений категорий анализа позволила сопоставить их смыслы и описать, каким образом преподаватели адаптируются к ситуации работы в виртуальной аудитории, как переопределяется содержание труда преподавателей в ситуации тотального онлайн-обучения, как перестраивается граница между работой и повседневностью в ситуации карантина.

\section{Преподавательский труд как ядро академической профессии в России}

Для того чтобы проанализировать изменения, которые произошли в содержании труда преподавателей в связи с переходом на онлайн-формат обучения, а также их временные и эмоциональные издержки, необходимо дать определение преподавательского труда, выделить его компоненты и обозначить место преподавания в современной академии. Устройство академической профессии строится на императивном сочетании различных типов деятельности, осуществляемых сотрудниками вузов. Преподавательский труд является частью академической

\footnotetext{
${ }^{2}$ Statement of Ethical Practice //British Sociological Association. 2017. URL: https://www.britsoc.co.uk/media/24310/ bsa_statement_of_ethical_practice.pdf (accessed: 23.05.2021).
} 
профессии и неразрывно связан с другими формами академического труда наряду с исследованиями и администрированием. Социальные иерархии внутри академической профессии связаны с диспозициями власти, существующими в рамках академического поля [Бурдье, 2018]. В частности, разные виды академического труда могут иметь разный символический вес [Magoqwana, Maqabuka, Tshoaedi, 2019]. В российских вузах временно́е соотношение разных видов академического труда (преподавание, исследование, администрирование) и символическая стоимость каждого варьируются в зависимости от статуса вуза. При этом преподавательская деятельность остается ядром данной профессии [Соколов, 2015: 561]. Вне зависимости от статуса вуза, наукометрических показателей и позиции в административной иерархии для подавляющего большинства профессорскопреподавательского состава вузов аудиторная нагрузка, связанная с чтением лекций и ведением семинаров, является основой для оценки трудовой нагрузки и оплаты труда.

Формально содержание непосредственно преподавательского труда регламентируется действующим законодательством и включает такие виды работ, как учебная, учебно-методическая, научно-исследовательская, а также другие виды деятельности, непосредственно связанные с выполнением педагогических функций ${ }^{3}$. Учебная составляющая преподавательского труда связана с разработкой дизайна курса (содержательный план занятий, сценарии проведения семинарских занятий, проверочные задания промежуточного и итогового контроля), проведением лекций и семинаров в аудитории, проверкой и оцениванием знаний и результатов обучения студентов. Она является "Видимой" частью работы преподавателя с высокой степенью подотчетности администрации вуза (соблюдение расписания занятий, предоставление программы курса, оформленной в соответствии с формальными требованиями, сдача ведомостей по итоговой аттестации), коллегам (содержание курса), студентам (способы самопрезентации преподавателей, содержание курса, соблюдением преподавателями формальных правил и пр.). Пространство аудитории или кафедры максимально способствует видимости преподавательского труда, когда возникает ситуация соприсутствия разных участников образовательной коммуникации, наблюдающих и оценивающих действия друг друга (например, обсуждение и утверждение программ курсов, взаимное посещение преподавателями занятий). Локализация курса в сетке учебного расписания и конкретной аудитории в здании университета позволяет легко контролировать работу преподавателя со стороны администрации, коллег и студентов. А также институциональные нормы и правила взаимодействия задают формируемые университетскими структурами (организация университетского пространства, оборудование, локальные регламентирующие документы, внутренние

\footnotetext{
${ }^{3}$ В соответствии с «Законом об образовании” №273ФЗ от 29.12.2012, приказом Минобрнауки России от 19.12.2013 № 1367 «Об утверждении порядка организации и осуществления образовательной деятельности по образовательным программам высшего образования - программам бакалавриата, программам специалитета, программам магистратуры", приказом Минобрнауки России от 22.12.2014 № 1601 “О продолжительности рабочего времени (нормах часов педагогической работы за ставку заработной платы) педагогических работников и о порядке определения учебной нагрузки педагогических работников, оговариваемой в трудовом договоре", и "Примерными нормами времени для расчета объема учебной работы и основных видов учебно-методической, научно-исследовательской выполняемых профессорско-преподавательским образовательных учреждениях высшего и профессионального образования" (Приложение к письму Минобразования России от 26.06.2003 № 14-55-784ин/15).
} 
университетские должностные иерархии) способы управления впечатлениями и выполнения эмоциональной работы.

"Невидимая" часть преподавательского труда включает работы, которые не учитываются или частично учитываются сеткой преподавательской нагрузки. Как правило, они осуществляются вне аудитории или пространства университета (например, подготовка к занятиям, научное руководство курсовыми работами и ВКР студентов), а потому незаметны и сложно поддаются внешнему контролю и адекватной оценке трудозатрат преподавателя по формальным критериям. Такие типы работы могут поглощать достаточно много времени и сил преподавателей, однако они, как правило, не только игнорируются формальными правилами трудовых отношений и контролирующими агентами, но часто не замечаются и самими преподавателями. К таким работам также можно отнести профессиональное саморазвитие, поддержание коммуникации со студентами вне аудитории (например, рассылка заданий к семинарам, оперативные ответы на письменные вопросы студентов, координация их учебной работы вне аудитории и пр.). Сюда же могут быть отнесены работы, находящиеся в "серой зоне" учета преподавательской нагрузки,- - они хотя и включаются в формальные нормативы рабочего времени, но фактическое их выполнение может существенно превышать эти нормы (например, учебно-методическая работа, проверка домашних работ студентов, научное консультирование студентов).

Эмоциональный труд может рассматриваться как составная часть всех видов преподавательской деятельности, пронизывая как ее "видимую", так и “невидимую" части. Наиболее ярко он проявляется в аудитории во время учебной коммуникации со студентами, но также присутствует во всех видах личного или опосредованного взаимодействия с учащимися [Bloch, 2012].

\section{Видимая работа: перформанс перед агентами внешнего контроля и эмоциональный труд}

Работа в аудитории в ситуации взаимодействия преподавателя и студентов лицом к лицу рассматривается нами как наиболее видимая часть труда преподавателя, требующая управления не только своими эмоциями, но и работы по поддержанию внимания, вовлеченности и позитивного эмоционального фона аудитории. По оценкам респондентов, "горловая нагрузка" составляет от 20 \% до 60 \% всего рабочего времени. В приведенной ниже цитате из интервью информантка описывает распределение своих обязанностей в университете следующим образом:

Наверное, если взять все мое рабочее время, то преподавание - это процентов двадцать. Общение со студентами - двадцать, подготовка - тридцать. Итого семьдесят получилось. И по пятнадцать административная и научная деятельность. (Ж., преподаватель визуальных искусств)

Преподавание в аудитории требует от преподавателей эмоциональной работы, связанной с перформансом и игрой на аудиторию. Как сказала одна из информанток, “выход в класс - это всегда немного „театр“»(Ж., преподаватель истории искусств). 
С точки зрения микросоциологии аудитория с имеющимся в ней оборудованием (мебель, мультимедийные средства, доска, кафедра и пр.) представляет собой специфический фрейм социального взаимодействия, который задает способы взаимодействия, типичные для публичного пространства, а также соответствующий набор способов презентации себя, управления впечатлением, демонстрации степени вовлеченности, характерных для роли учителя и учеников. Институциональные структуры берут на себя управление эмоциями, изымая некоторые правила индивидуального актерского исполнения и замещая их институциональными механизмами [Хокшилд, 2019: 147]. Таким образом, преподавательский труд в аудитории, в том числе его эмоциональные компоненты, формализован и структурирован институциональными правилами, которые складываются в контексте неолиберального университета.

Характеризуя используемый фрейм аудиторного взаимодействия, информанты отмечают, что стараются отойти от жестко формализованного взаимодействия в виде лекций как монологичного изложения материала, а также от жесткого разделения на лекционные и семинарские занятия, при котором одна форма занятий включает трансляцию информации, а другая - проверку знаний учащихся. Респонденты активно внедряли интерактивные формы занятий до перехода на онлайн-формат обучения. Следующие цитаты иллюстрируют способы проведения учебных занятий:

В лекциях скорее мы стремились к диалогу. Если говорить о традиционности, то диалога [стало] больше. А семинары - мы со студентами читали тексты, использовали техники письма и мышления, плюс проектную работу, раз в модуль они могли защитить цифровой проект, снять видеоролик. Непосредственно читаем текст, обсуждаем, пишем по нему, много рефлексии и проекты групповые <...> Провожу занятия смешанного типа: лекция плюс семинар условно. То есть в рамках одного занятия смешиваю лекционный формат и интерактивный формат: работа в малых группах, творческие задания типа нарисуйте афишу фильма, напишите эссе на карточках. (Ж., преподаватель визуальных искусств)

Интерактивные формы занятий требуют от преподавателя владения техники поддержания постоянного внимания и заинтересованности студентов (например, через вопросы к аудитории и диалог), а также близкой межличностной коммуникации (преподаватели используют местоимение "мы", говоря о работе со студентами). Информанты говорят, что стараются заинтересовать аудиторию, поддержать визуальный контакт со слушателями, запоминают имена студентов, стараются одеваться, как профессионалы. Участвующий стиль коммуникации предполагает динамичное реагирование на происходящее (вопросы студентов, их невербальные реакции), чтобы подстроить содержание занятия под запросы конкретной аудитории. Преподавателям приходится раскрывать личную информацию о себе или делиться личностным опытом для управления вниманием аудитории. Цитата ниже представляет собой рассказ о стиле ведения лекционного занятия, во время которого преподаватель постоянно считывает реакцию аудитории и отвечает на нее, переструктурируя заготовленные материалы: 
Когда я веду занятие в офлайне, мне очень важно видеть реакцию, на что люди реагируют, какая тема для них более актуальна сейчас, о чем они думают, кто сомневается. Иногда человек показывает, что он сомневается, но не говорит, что он сомневается. Я могу остановиться и проговорить: "Мне кажется, вы сомневаетесь в моих словах. Давайте проговорим". (М., преподаватель психологических наук)

Такие формы интерактивной работы отличны от традиционных режимов преподавания, при которых лектор нейтрально, отстраненно осуществляет дисциплинарное высказывание. Интерактивный режим требует навыков установления непринужденной, живой коммуникации, а также умения поддерживать позитивный эмоциональный фон в аудитории. При этом негативные эмоции (раздражение, скука, злость, агрессия) не демонстрируются преподавателем, представляя собой табу. В этом смысле интерактивный режим преподавания включает значимый компонент эмоционального труда по приведению своих эмоций и эмоций в аудитории в соответствие с конвенциональными ожиданиями “интересного занятия", "заинтересованности студентов".

Сами преподаватели рассматривают популярность своих курсов как подтверждение собственного профессионализма и качества работы. Кроме того, неолиберальные принципы оценивания работы преподавателей учитывают формальные рейтинги, выставляемые студентами. В случае курсов по выбору (которые присутствуют в учебных планах всех российских вузов) популярность преподавателя в студенческой аудитории непосредственно влияет на вероятность выбора читаемых им курсов в дальнейшем и, соответственно, гарантирует наличие у него аудиторной нагрузки. Чтение авторского курса также повышает академический капитал преподавателя и способствует его профессиональной автономии. В целом преподаватели полагают, что использование интерактивных режимов повышает заинтересованность, мотивацию студентов, приводит к более эффективному усвоению материалов курса и в конечном счете сказывается на более высоких оценках со стороны студентов.

У меня довольно высокий рейтинг среди студентов, поэтому у меня никогда не было проблем с прохождением конкурса. Я серьезно вкладываюсь в преподавание, стараюсь использовать самую новую литературу по теме, но еще и слежу за методиками преподавания, у меня много игр, викторин и дебатов на занятиях. Я вообще считаю, что живые примеры из жизни для анализа на семинарах необходимы. И, конечно, шутки, развлекухи разные - это обязательно, смех разряжает эмоциональное напряжение и позволяет легче запоминать материал. (М., преподаватель международных отношений)

Несмотря на то, что интерактивный режим преподавания требует высокой степени включенности в процесс коммуникации со студентами, респонденты не описывали его в категориях эмоционального труда, то есть не проблематизировали свои усилия и затраты на выполнение данной работы, напротив, подчеркивая те позитивные личностные результаты, которые они получают (удовлетворение от работы, эмоциональный отклик аудитории, подъем настроения после удачно 
проведенного занятия). Респонденты считают, что работа в аудитории вознаграждается как в форме академической и профессиональной репутации, так и форме субъективного удовлетворения от своего труда.

Вынужденный переход на дистанционный формат преподавания был связан с перестройкой преподавательских практик в соответствии с изменившимися условиями коммуникации. Фрейм онлайн-обучения не предполагает ситуации взаимодействия лицом к лицу. Коммуникация оказывается полностью опосредованной техническими средствами, которые задают другой (по сравнению с ситуацией личного общения) набор средств самопрезентации. Поддержание интерактивного формата образования в онлайн-среде оказывается, по словам информантов, более “эмоционально затратным" по сравнению с офлайн-занятиями. Сравнивая свой опыт преподавания в реальной и виртуальной аудитории, преподаватели говорят не столько об изменениях в дизайне курса (адаптировать лекционные и семинарские занятия к требованиям онлайн-образования), сколько об "усталости", "эмоциональных затратах", необходимости тратить больше "энергии", которые были связаны с выполнением эмоциональной работы онлайн:

У меня эмоциональные затраты значительно больше, я очень устаю. После обычных моих 4,5 часов онлайна я устаю значительно больше, чем я уставала в офлайне, потому что у меня ощущение, что я не добиваю. А когда я не добиваю, я трачу больше энергии, чтобы объяснить, сказать, и потом мне кажется, что я должна более выразительно эмоционально говорить, акцентировать на чем-то внимание голосом, или, когда я у них в кадре, жестом, мимикой. Соответственно, я в это вкладываю значительно больше энергии, чем раньше я вкладывала, поэтому я больше устаю, безусловно. То есть мои затраты временньіе, эмоциональные, физические значительно больше на дистанте, чем были до того. (Ж., преподаватель филологии)

Респонденты говорят о дополнительных усилиях в ситуации дистанционной учебы, которые можно описать как работу, направленную на поддержание вовлеченности студентов в ситуацию занятия: необходимо говорить "больше», четче артикулировать звуки, использовать модуляции голоса, активно жестикулировать, сопровождать слова дополнительной мимической экспрессией.

Почему-то полтора часа в аудитории не отнимали столько сил, сколько полтора часа в онлайне. Я это связываю с тем, что, во-первых, дабы сохранять вовлеченность студентов в само занятие, преподаватель должен больше говорить, то есть гораздо больше нагрузки стало на горло. Во-вторых, когда ты находился в ситуации, когда все были в одной аудитории, были какие-то шутки, какие-то улыбки, забавные моменты, то есть осуществлялась эмоциональная работа, которую в онлайне считать практически невозможно. Если раньше я мог отвести три пары и быть еще полным сил, нестись в другой корпус и заниматься там другой работой, то сейчас, как правило, я просто ложусь спать. У меня просто не остается сил. (М., преподаватель социальных наук)

Интенсификация эмоционального труда в ситуации онлайн-преподавания связана с наложением фрейма публичного взаимодействия в виртуальной ауди- 
тории и фрейма приватной коммуникации в домашнем пространстве. До конца учебного года (2019/2020) преподаватели проводили занятия, находясь дома. Это потребовало от многих реорганизации домашнего пространства, создания специального функционального и удобного рабочего места, а также способа самопрезентации в соответствии с требованиями фрейма публичной коммуникации в учебной аудитории. Кроме того, в ситуации дистанционной работы индивидам вменяется ответственность за (вос)производство устоявшихся форм трудовой деятельности, которая в ситуации офлайн-образования поддерживалась институциональным реквизитом (организация пространства, реквизит, структуры коммуникаций). Заходя в аудиторию, преподаватель своим положением в структуре пространства оказывался исполнителем соответствующей роли и источником авторитета. В ситуации онлайн-занятия соответствующий реквизит отсутствует, поэтому преподаватели были вынуждены компенсировать его дополнительной работой, в том числе эмоциональной. Таким образом, возникала интерференция фреймов в отсутствие возможности использовать физическое пространство университета как институциональный механизм управления впечатлением о себе. Это требовало интенсификации усилий по разграничению фреймов и производству своего преподавательского лица в онлайн-коммуникации.

Приведенная ниже цитата иллюстрирует интерференцию пространств разного типа, которую информант интерпретирует как "экспансию университета в приватность". Также он отмечает эмоциональный стресс, возникающий в результате нарушения сложившейся пространственной и темпоральной сегрегации дома и работы:

В университете есть своя среда: ты приходишь на работу. Взаимодействие в университете - это один уровень взаимодействия. Взаимодействие из дома - это другой уровень взаимодействия, это другой уровень психологической готовности к общению, и это тоже социальная проблема онлайнизации, когда пространство университета вырывается, но оно не расширяется на самом деле. Психологически расширить университет на квартиру очень сложно для преподавателя. (М., преподаватель политических наук)

Для переключения фреймов респонденты использовали одежду и обстановку: приступая к занятиям, они переодевались в "рабочую" одежду, женщины наносили макияж, подбирали яркие аксессуары, совершая своего рода ритуалы подготовки к презентации себя в виртуальной аудитории. Эти манипуляции с внешним видом можно рассматривать как способ осуществления эмоциональной работы по приведению своих чувств и эмоций в ситуации интерференции двух взаимоисключающих друг друга фреймов.

Я всегда одевался для себя, чтобы внутренне настроиться на работу. Я привык специально одеваться, это вводит меня в контекст - сейчас я буду преподавать. <...> Для меня это некоторая возможность собраться, внутренне понять, что сейчас я буду работать, надо включиться. <...> Мне кажется, что идея того, что "я сяду и до вот этого времени работаю", я одеваю рабочую одежду и иду в отдельную комнату. Я уходил, создавал ощущение работы, за исключением того, что мне не надо было тратить время 
на дорогу. Все [домашние] понимали: я сейчас работаю, меня старались не трогать. В перерывах я выходил, узнавал, как дела, мог сделать себе кофе, как если бы я пошел к автомату, и возвращался. В этом плане очень четко эти границы были сохранены: есть работа, есть домашние дела. (М., преподаватель психологических наук)

Работа на камеру рассматривается как способ поддержания включенности студентов в образовательный процесс и возможность продемонстрировать свой профессионализм, получить позитивный отклик от студентов:

Я всегда продумывала, что я надеваю. Для меня это равносильно выходу на работу. Это как процесс перехода на работу. <...> Я никогда бы не пошла на пару в домашних штанах. Это исключено. Я переодевалась полностью. <...> При этом я также думала, как это будет выглядеть на экране. <...> Я не хотела, чтобы дети что-то потеряли. Я популярный преподаватель, дети меня любят, и я люблю то, что дети меня любят, поэтому я знаю, что я харизматичная, и как бы я понимаю, что что-то там теряется в онлайне. Мне бы не хотелось показать им, что мне по фигу. (Ж., преподаватель визуальных искусств)

Я сразу прочитала, как надо выглядеть. Я всегда крашусь, хотя мне это не хочется. Редко-редко, когда я себе позволяю выйти ненакрашенной. Серьги, кольца, броши, платки нашейные - все это я активно использую, чтобы быть разной, веселой, бесконечно улыбаться, шутить, спрашивать в начале у студентов, как у них дела, что как, как они живут, все ли у них нормально, подбадривать их первые десять минут занятия. (Ж., преподаватель филологии)

Второй инструмент разграничения фреймов - работа с обстановкой, подбор реквизита, имитирующего ситуацию коммуникации на сцене. Особое внимание придается формированию визуального антуража и внешнего вида. Для многих то, как они смотрятся на экране, стало предметом особой рефлексии и направлением приложения усилий по созданию виртуального образа. Для респондентов появившиеся в период пандемии в популярных массмедиа инструкции по zoom-этикету стали руководством к действию, что выразилось в оборудовании "домашнего офиса" и управлении впечатлением о себе в ситуации онлайн-взаимодействия. Преподаватели говорят, что стараются убрать "из кадра" личные вещи и предметы интерьера, характеризующие обстановку как приватную. Они выбирают в жилом пространстве фон нейтральной стены или книжных полок, или выставляют настройки фона в коммуникационных платформах, используемых для проведения онлайн-занятий. Такой фон скрывает личную информацию, защищая от вторжения в приватность, а также позволяет поддержать исполнение роли преподавателя:

У меня тут рядом кухонный шкаф, окно. <...> Ну, это почему - у меня сзади белый фон. Если я сяду в комнату, у меня там будут вещи за спиной висеть, а здесь более-менее нейтральная ситуация. (М., преподаватель философии)

Для меня ключевым моментом было... Мне не очень хотелось, мне не очень приятно, когда люди проникают в частную жизнь без моего разрешения. Конечно, когда ты 
включаешь камеру дома, то, естественно, я начал задумываться о том, что попадает на заднем плане в кадр. Потом я достаточно быстро, со второй недели, нашел место у стены, по сути, нейтральное место, поставил стол, стул. После этого не было дальше проблем с камерой никаких. (М., преподаватель психологических наук)

У меня кресло, столик. Поднятый достаточно на книгах, стоит мой компьютер, чтобы он был на уровне моего лица. Лампы стоят, которые меня хорошо освещают, сзади книжная полка, чтобы казаться умной, очёчки. Собственно говоря, весь этот традиционный антураж у меня соблюден. (Ж., преподаватель филологии)

Некоторые респонденты в ситуации интенсификации усилий, в том числе эмоциональных, возникающей при онлайн-формате преподавания, выбирают стратегию минимизации эмоциональных затрат, ссылаясь на удобство работы без постоянно включенной камеры как для себя, так и для студентов.

Я не хочу требовать от студентов их постоянного взгляда. <...> Если они хотят пить чай по ходу лекции, они абсолютно в этом праве. Для этого, если они сидят в отключенном видео или аудио, я не против. <...> Что касается меня, то выход в класс - это тоже всегда немного "театр", и тут есть "вызовы" этой ситуации. Когда все это происходит из дома, я предпочитаю выключать камеру и вещать из-за кадра. Считаю, что это вполне подходит к данному формату. <... Н Ну, просто это ради собственного удобства. Просто чтобы не тратить энергию на то, как ты выглядишь в камере. Иногда я прошу включить камеру в начале или в конце занятия, просто чтобы поговорить. (Ж., преподаватель истории искусств)

Вместе с тем преподаватели говорили о том, что камера и возможность визуального контакта со студентами и коллегами выступали средствами создания фрейма ситуации занятия, поэтому, несмотря на интенсификацию эмоционального труда на карантине, они не могли от них отказаться.

Я выключала камеру только на перерыв. Мне даже не приходило в голову, что я могу не включить камеру. Студенты должны меня видеть. Я, когда рассказываю, руками размахиваю. Мне было некомфортно общаться с экраном компьютера, но когда там есть студенты, то терпимо. Тяжело психологически не видеть живых людей, без социального взаимодействия тяжело. (Ж., преподаватель визуальных искусств)

В ситуации вынужденной изоляции и экстренного перехода на онлайн-формат обучения преподаватели обнаружили, что прежние способы управления впечатлением не работают или их поддержание требует значительных эмоциональных и временнб́х затрат. Они старались выработать новые способы самопрезентации и ведения занятий, стремились минимизировать усилия в ситуации возросших требований к выполнению дополнительной работы. Тем не менее административная логика контроля работы ППС в российских университетах была по-прежнему связана с учетом аудиторных и контактных часов преподавательского труда. Более того, возможности внешнего контроля благодаря введению дистанционных 
технологий были расширены за счет внешнего онлайн-подключения к занятиям представителей администрации различного уровня, мониторинга цифровых следов занятий или слежения за заполнением электронных ведомостей в режиме реального времени. Например, технические возможности MS Teams позволяют отслеживать продолжительность онлайн-трансляции занятия, список подключившихся студентов, время и дату публикации преподавателями материалов к лекционным и семинарским занятиям, просмотр и выполнение студентами заданий по курсу, переписку между преподавателем и студентами курса. Доступные технические средства (включение/выключение камеры и микрофона) предоставили участникам учебного взаимодействия возможности осуществления тактик сопротивления возросшему внешнему контролю и требованиям выполнения дополнительной работы.

\section{Невидимая работа: императив эмоционального труда и заботы об эмоциональном благополучии студентов}

К невидимой работе нами были отнесены такие формы труда преподавателя, которые осуществляются им вне аудитории и которые сложно поддаются внешнему контролю. Они являются, по мнению респондентов, важной частью их профессионализма, поскольку связаны с их популярностью среди студентов, которая интерпретируется как оценка конечными получателями их услуг. Здесь мы рассматриваем прежде всего различные формы коммуникации со студентами, к которым относятся оперативные ответы на вопросы студентов; их информирование о расписании, содержании занятий, текущих оценках; рассылка материалов и заданий по курсам, сбор письменных работ студентов и пр. Данный вид деятельности обычно не выделяется и не учитывается как отдельный тип нагрузки ППС, однако в интервью преподаватели отмечали, что он составлял значимую часть их рабочего времени и требует отдельных организационных и эмоциональных усилий.

До введения режима самоизоляции администрации университетов пытались организовать и структурировать каналы коммуникации преподавателей со студентами при помощи внутриуниверситетских коммуникационных сред, таких как Blackboard, LMS, Sakai, Moodle и др., а также корпоративной почты. Преподаватели отмечали, что наряду с университетскими платформами также активно использовали социальную сеть "ВКонтакте» (специально созданные паблики), мессенджеры (WhatsApp) для того, чтобы разместить материалы курса, а также обмениваться со студентами оперативной информацией. При этом использование мессенджеров и социальных сетей часто представлялось в качестве дополнительного более эффективного средства для связи.

У нас существует паблик "ВКонтакте", они охотно туда добавляются. <...> Через этот паблик мы и коммуницируем, и домашние задания, и какие-то тексты предлагаем. <..> Наших студентов нигде больше нет. Они все есть во “ВКонтакте». (Ж., преподаватель философии)

Естественно, мы обменивались текстами. У меня у каждой группы всегда есть группа в WhatsApp для быстрой коммуникации, есть, естественно, почтовый адрес, на который 
я получаю от них работы и чаще всего переписываюсь с ними по поводу их деятельности учебной. (Ж., преподаватель филологии)

Я пользовался Sakai и BlackBoard. Иногда, если создавался студентами чат, например "ВКонтакте", я мог туда написать, что "обратите внимание, я выложил задание". Само задание не выкладывал, а просто информировал о том, что задание появилось. (М., преподаватель психологических наук)

Преподаватели представляли режим коммуникации со студентами до карантина как коммуникацию структурированную, контролируемую, в большой степени формализованную. Они отвечали на письма студентов только в рабочее время или отводили для этого отдельные часы в течение дня или рабочей недели. Таким образом они пытались выстроить границу между рабочим и нерабочим временем, а также поддерживать социальную дистанцию и властную диспозицию, создавая таким образом "статусный щит" и управляя своими эмоциональными усилиями.

Я была вообще против общения в соцсетях со студентами. Регламента не было, мне дети писали в любое время, а я отвечала им только в рабочие часы. (Ж., преподаватель визуальных искусств)

Я предупреждаю [студентов], что я имею право ответить в удобное мне время. (М., преподаватель психологических наук)

Процесс перехода на онлайн-формат обучения весной 2020 г. для респондентов стал неожиданностью и сопровождался ощущением неопределенности и стрессом. Преподаватели по-разному отвечали на вызовы новой коммуникативной реальности. При этом в нашей выборке отчетливо заметны гендерные различия в формах и способах осуществления эмоциональной работы в данной ситуации. Данное наблюдение согласуется с результатами многочисленных исследований эмоционального труда в академии, которые показывают, что женщины-преподавательницы с большей вероятностью по сравнению с мужчинами вовлекаются в различные формы академической работы, требующие осуществления эмоционального менеджмента в отношении студентов и коллег. Они стараются соответствовать ожиданиям, которые существуют применительно к ним на основании гендера. Такие ожидания являются результатом трансляции материнских “естественных" функций в публичное пространство. Принципы детско-родительских отношений и интенсивного материнства переносятся в университет и реализуются в студенто-ориентированной модели коммуникации [Lawless, 2018: 90]. Показательно, что некоторые респонденты называют студентов в интервью детьми, говорят, что они «еще маленькие», транслируя модель интенсивной заботы, где женщина выступает ее основным поставщиком. Переход на онлайн-формат привел к интенсификации заботы и эмоциональной работы, осуществляемой женщинами-преподавательницами:

Первое, что я сделала, это всем отправила письмо и поставила ссылку на группу во "ВКонтакте". Я сразу создала группу во “ВКонтакте", добавила их всех в друзья. 
У меня закрытая страница, я принципиально против общения со студентами в соцсетях, но тут была совершенно другая ситуация, поэтому пришлось мне своими принципами поступиться. Мы создали группу, и мне было очень важно с ними встретиться так, чтобы они тоже могли что-то сказать, потому что они тоже были взволнованы, напуганы, и я понимала, что они гораздо больше взволнованы и напуганы-гораздо больше, чем я. Потому что они маленькие, какие бы ни были взрослые. (Ж., преподаватель визуальных искусств)

Когда начался онлайн весной, то я практически бесконечно переписывалась [со студентами], особенно в первые дни [самоизоляции], потому что я понимаю-дети были в стрессе. (Ж., преподаватель истории искусств)

Преподаватели мужчины и женщины по-разному выстраивали границы между рабочим и нерабочим временем и режимы доступа себя для коммуникации. Преподавательницы были более склонны отводить все свое время для онлайнобщения со студентами. При этом они рассматривали свою "доступность" как элемент профессионализма и признак хорошего выполнения преподавательских обязанностей. Таким образом, профессиональные идентификации оказываются гендерно специфицированными.

Я теперь нахожусь в бесконечном доступе, они мне пишут: “А можно мы с вами поговорим? А можно обсудить с вами главу?", и я не считаю возможным им в этом отказать, и вечером я очень много консультаций провожу сейчас со студентами, которые хотят этих консультаций, я их не ограничиваю. Естественно, времени у меня очень мало свободного. <...> Я стала доступнее студентам, эти студенты меня дергают, и я не отказываю им. <...> У меня нет такого регламента внутреннего. У меня нет такого, что мне нельзя звонить в мои выходные дни или после одиннадцати писать. Я как раз наоборот даже с ними встречаюсь в Zoom в 9-10 вечера, когда я освобождаюсь от занятий, делаю небольшой перерыв после занятий, которые у меня заканчиваются где-то в 5-6 часов, и тогда я уже с ними обсуждаю. Поэтому они ночные существа, и я ночное существо, у меня нет таких регламентов. (Ж., преподаватель филологии)

Тратишь больше времени на работу, не знаю почему. То ли, может, дети как-то больше вопросов задают в этом "ВКонтакте", начинаю все время всем отвечать, и ты как бы все время там с ними переписываешься, чтобы им не было ни одиноко, ни тоскливо. Нет вот этой грани, что ты вышел из университета - тебя нет, никто тебя не долбает. А тут ты включил телефон, а тебе там пять сообщений "ВКонтакте", и ты на них начинаешь отвечать в девять вечера. Может, в этом дело, не знаю. Но у меня было ощущение, что я трачу на работу больше времени. (Ж., преподаватель визуальных искусств)

Очень много, я не могу оценить в часах, но мне студенты могут написать в 11 ночи, я им отвечаю, если я онлайн. У меня растягивается рабочий день таким образом, у него нет границ никаких. В любой момент по запросу студентов я доступна, я готова с ними работать. <...> Я, конечно, ориентирую их, говорю, что вы имейте в виду, что у меня тоже бывают выходные, поэтому не надо, если у вас дедлайн в воскресенье, не думайте, 
что я в субботу вам быстро отвечу. Я их дисциплинирую в том плане, что у них есть дедлайн, до него они должны все сделать, и это не значит, что я им за час до сдачи работы что-то порекомендую. Но при этом они знают, что они мне могут написать и в субботу, и в воскресенье, и я, может, не сразу, но в течение дня точно отвечу. У меня нет запрета писать мне в нерабочее время. (Ж., преподаватель политических наук)

Мужчины-преподаватели редко упоминали в интервью формы коммуникации со студентами вне формальных занятий, что заставляет предположить низкую значимость такой коммуникации как формы профессиональной активности. В некоторых случаях респонденты мужского пола говорили о коммуникации со студентами, интерпретируя свой профессионализм через умение регламентировать и структурировать эту коммуникацию, четко разграничивать рабочее и нерабочее время, а также структурировать рабочее время с точки зрения выполнения разных видов задач.

У меня время организовано очень комфортно. <...> Принцип очень простой: я просыпаюсь в 6 часов и до 9 я про работу ничего не знаю. До 9 часов я абсолютно никак не контактирую с рабочим пространством, ничто меня не интересует в этот момент. Три часа у меня абсолютно на себя, на завтраки, на физическую активность, на восстановление сил. И только в 9 часов я открываю корпоративную почту, начинаю сортировать задачи. Проверяю работы, поступившие от студентов. Это занимает порядка двух часов ориентировочно. С 11 у меня есть онлайн-занятия, встречи, се минары. Это все до обеда - с 11 до 13. В 13 обед. После часа, если нет занятий онлайн, у меня свободное саморазвитие. Я проверяю вечером почту, новости у меня утром и вечером просматриваются. С шести часов вечера я никак не контактирую с работой абсолютно, ничего о ней не знаю, если нет никаких срочных мероприятий. В 6 часов уже работы никакой нет, в 10 часов спать. <...> Несмотря на все ухищрения администрации, я никак не реагирую ни на какие письма, ни на какую студенческую активность. Не может быть срочных дел, которые нельзя решить потом. (М., преподаватель биологии)

Таким образом, невидимая работа занимала и до карантина достаточный объем рабочего времени ППС, однако в период дистанционного обучения ее объем возрос в связи с необходимостью как освоения новых дистанционных технологий, так и дополнительной работы по коммуникации со студентами, большей подотчетностью администрации и родителям (которые также получили возможность подключаться к дистанционным занятиям).

Одновременно увеличение объема невидимой работы и ее эмоциональной компоненты, по всей видимости, привело к усилению статусных неравенств внутри академии. Женщины, которые традиционно в академии выполняли функции социального материнства, в большей степени включились в коммуникацию со студентами, направленную на поддержание не только формальной стороны образовательного процесса, но и их эмоционального благополучия. Таким образом, возросшие требования в отношении эмоциональной работы оказались распределены по линиям гендерного неравенства академии. 


\section{Заключение}

На основе анализа материалов полуструктурированных фокусированных интервью с преподавателями четырех российских университетов было показано, как изменилось содержание преподавательского труда в связи с вынужденным массовым переходом на дистанционный формат обучения. Также мы выяснили, каким образом в новых структурных условиях преподаватели адаптировали старые и вырабатывали новые практики обучения и модели взаимодействия со студентами в виртуальном учебном классе. Проведенное исследование позволило сделать вывод, что онлайнформат обучения потребовал от преподавателей существенного увеличения временнб́х и эмоциональных затрат. Мультипликационный эффект, возникший в результате наложения правил функционирования неолиберальной академии и вынужденного массового перехода на онлайн-формат обучения, актуализировал место и объем эмоционального труда, выполняемого преподавателями, в учебном процессе.

Введение в анализ эмоциональной компоненты преподавательского труда позволило по-новому взглянуть на содержание как видимой, так и невидимой компоненты преподавания. Оно также дало возможность обратить внимание на неравенства, характерные для поля университетов и скрытые логикой академической эффективности, выражающейся в рейтингах студенческих оценок преподавателей, показателях публикационной и грантовой активности, количествах контактных аудиторных часов и пр. Гендерные аспекты труда преподавателей стали более очевидными в условиях пандемии и режима вынужденной самоизоляции.

Эмоциональная составляющая труда преподавателей остается невидимой со стороны агентов внешнего контроля, выступая неотьемлемым элементом образования как услуги, которую предлагают университеты на образовательном рынке. Очевидно, что наложение логики неолиберальной академии и дистанционного образования будет приводить к увеличению объемов эмоционального труда преподавателей в структуре всех форм их работы. Это также потребует выработки новых подходов к управлению современными университетами с учетом невидимого, но ключевого их компонента - эмоций.

Вызов для современных университетов представляет и возрастание спроса со стороны студентов на эмоционально комфортное и безопасное пространство обучения. Данный спрос задан развитием эмоционального капитализма [IIlouz, 2007], когда психологическое благополучие становится ценностью, достижение которой предполагает наличие определенных знаний о психическом здоровье, факторах и рисках, способствующих его дестабилизации, а также способах его поддержания. Массовое освоение языка популярной психологии поддерживает внимание к состоянию внутреннего "я", психологическому здоровью, позволяющему идентифицировать такие психологические состояния, как депрессия, эмоциональное выгорание, стресс, обесценивание личного опыта и переживаний, и пр. [Gershon, 2011]. Студенты как потребители образовательных услуг требуют не только физической, но и эмоциональной безопасности, становясь более чувствительными к микроагрессии и микронасилию. Данный тренд также потребует переосмыслить содержание преподавательского труда как одного из видов академической профессии и приведет к увеличению нагрузки на преподавателей с точки зрения выполнения ими эмоциональной работы. 


\section{Список литературы (References)}

Абрамов Р.Н. Менеджериализм: экономическая идеология и управленческая практика // Экономическая социология. 2007. Т. 8. № 2. С. 93-102. https:// doi.org/10.17323/1726-3247-2007-2-92-101.

Abramov R. N. (2007) Managementism: Economic Ideology and Management Practice. Economic Sociology. Vol. 8. No. 2. P. 93-102. https://doi.org/10.17323/1726-32472007-2-92-101. (In Russ.)

Абрамов Р.Н. Менеджериализация и трудовые порядки университетской жизни: Российский и международный контексты // Социологический ежегодник, 20152016. М: ИНИОН РАН, 2016. С. 140-155.

Abramov R. N. (2016) Management and Labor Orders of University Life: Russian and International Contexts. Sociological Yearbook, 2015-2016. Moscow: INION RAN. P. 140-155. (In Russ.)

Абрамов Р., Груздев И., Терентьев Е., Захарова У., Григорьева А. Университетские преподаватели и цифровизация образования: накануне дистанционного форсмажора //Университетское управление: практика и анализ. 2020. Т. 24. № 2. C. 59-74. https://doi.org/10.15826/umpa.2020.02.014.

Abramov R. N., Gruzdev I. A., Terentev E. A., Zakharova U.S., Grigoryeva A. V. (2020) University Professors and the Digitalization of Education: on the Threshold of Force Majeure Transition to Studying Remotely. University Management: Practice and Analysis. Vol. 24. No. 2. P. 59-74. https://doi.org/10.15826/umpa.2020.02.014. (In Russ.)

Абрамов Р.Н., Груздев И. А., Терентьев Е. А. Баланс работы и личной жизни и источники стресса научно-педагогических работников российских исследовательских университетов // Мониторинг общественного мнения: экономические и социальные перемены. 2019. № 3. С. 8-26. https://doi.org/10.14515/monitoring.2019.3.02. Abramov R. N., Gruzdev I. A., Terentiev E. A. (2019) Work-Life Balance and Sources of Stress for the Academic Staff in Russian Research Universities. Monitoring of Public Opinion: Economic and Social Changes. No. 3. P. 8-26. https://doi.org/10.14515/ monitoring.2019.3.02. (In Russ.)

Бурдье П. Homo academicus. М. : Изд-во Института Гайдара, 2018.

Bourdieu P. (2018) Homo academicus. Moscow: Gaidar Institute Publ. (In Russ.)

Дим Р. "Новый менеджериализм" и высшее образование: управление качеством и продуктивностью работы в университетах Великобритании // Вопросы образования. 2004. № 3. С. 44-56.

Deem R. (2004) 'New Managerialism' and Higher Education: The Management of Performances and Cultures in Universities in the United Kingdom. Voprosy obrazovaniya/Educational Studies Moscow. No. 3. P. 44-56. (In Russ.)

Перес К. Невидимые женщины. Почему мы живем в мире, удобном только для мужчин. Неравноправие, основанное на данных. М. :Альпина Диджитал, 2019. Perez K. (2019) Invisible Women: Exposing Dat a Bias in a World Designed for Men. Moscow: Alpina Digital. (In Russ.) 
Прудников М. В. Академическая профессия и университет в контексте исторической роли идей высшего образования и современных институциональных реформ // Социологический ежегодник, 2015-2016. М. : ИНИОН РАН, 2016. C. $156-165$.

Prudnikov M. V. (2016) Academic Profession and University in the Context of the Historical Role of Higher Education Ideas and Contemporary Institutional Reforms. Sociological Yearbook, 2015-2016. Moscow: INION RAN. P. 156-165. (In Russ.)

Соколов М. Политическая экономия организаций, сети и академические культуры в российской социологии // Соколов М., Губа К., Зименкова Т., Сафонова М., Чуйкина С. Как становятся профессорами: академические карьеры, рынки и власть в пяти странах. М. : НЛО, 2015. С. 458-676.

Sokolov M. (2015) The Political Economy of Organizations, Networks and Academic Cultures in Russian Sociology. In: Sokolov M., Guba K., Zimenkova T., Safonova M., Chuikina S. How You Become Professors: Academic Careers, Markets and Power in Five Countries. Moscow: New Literary Observer. P. 458-676. (In Russ.)

Хокшилд А. Управляемое сердце. Коммерциализация чувств. М. : Дело, 2019.

Hochschild A. (2019) The Managed Heart: Commercialization of Human Feeling. Moscow: Delo. (In Russ.)

Шпаковская Л. Политика высшего образования в Европе и России. СПб. : Норма, 2007.

Shpakovskaya L. (2007) Higher Education Policy in Europe and Russia. St. Petersburg: Norma. (In Russ.)

Allen M. (2017) Qualitative Publishing in a Neoliberal Universe and University. Cultural Studies $\leftrightarrow$ Critical Methodologies. Vol. 17. No. 3. P. 214-220. https://doi.org/ $10.1177 / 1532708616669527$.

Bloch C. (2012) Passion and Paranoia: Emotions and the Culture of Emotion in Academia. Burlington, VT: Ashgate.

Darder A. (2012) Neoliberalism in the Academic Borderlands: An On-going Struggle for Equality and Human Rights. Educational Studies. Vol. 48. No. 5. P. 412-426. https:// doi.org/10.1080/00131946.2012.714334.

Flick U. (2006) An Introduction to Qualitative Research. London: Sage.

Gershon I. (2011) Neoliberal Agency. Current Anthropology. Vol. 52. No. 4. P. 537-555. https://doi.org/10.1086/660866.

Giroux H. (2002) The Corporate War Against Higher Education. Workplace. A Journal for Academic Labor. Vol. 9. P. 103-117.

Gretzky M., Lerner J. (2021) Students of Academic Capitalism: Emotional Dimensions in the Commercialization of Higher Education. Sociological Research Online. Vol. 26. No. 1. P. 205-221. https://doi.org/10.1177/1360780420968117.

Illouz E. (2007) Cold Intimacies: The Making of Emotional Capitalism. Cambridge: Polity Press. 
King K., Hurst G., Lewis Z. (2020) Let's Emerge From the Pandemic Lockdown Into a Fairer Academic World. Current Biology. Vol. 30. No. 14. https://doi.org/10.1016/ j.cub.2020.06.034.

Larson H. A. (2008) Emotional Labor: The Pink-Collar Duties of Teaching. Currents in Teaching and Learning. Vol. 1. No. 1. P. 45-56.

Lawless B. (2018) Documenting a Labor of Love: Emotional Labor as Academic Labor. Review of Communication. Vol. 18. No. 2. P. 85-97. https://doi.org/10.1080/153 58593.2018.1438644.

Magoqwana B., Maqabuka Q., Tshoaedi M. (2019) “Forced to Care" at the Neoliberal University: Invisible Labour as Academic Labour Performed by Black Women Academics in the South African University. South African Review of Sociology. Vol. 50. No. 3-4. P. 6-21. https://doi.org/10.1080/21528586.2020.1730947.

Schwartz J. M. (2014) Resisting the Exploitation of Contingent Faculty Labor in the Neoliberal University: The Challenge of Building Solidarity Between Tenured and NonTenured Faculty. New Political Science. Vol. 36. No. 4. P. 504-522. https://doi.org/ 10.1080/07393148.2014.954803.

Slaughter S., Rhoades G. (2004) Academic Capitalism and the New Economy: Markets, State, and Higher Education. Baltimore, MD; London: The Johns Hopkins University Press.

Winslow S., Davis Sh. (2016) Gender Inequality Across the Academic Life Course. Sociology Compass. Vol. 10. No. 5. P. 404-416. https://doi.org/10.1111/soc4.12372. 